\title{
COVID-19 Pandemic Strategies in Tourism Activity as Guidelines for Ex-Yugoslavia Countries Tourism Recovery
}

\author{
Andrej Agačević ${ }^{1} \&$ Ena Jusufbegović ${ }^{2}$ \\ ${ }^{1}$ Glorius Sun School of Business and Management, Donghua University, Shanghai, China \\ ${ }^{2}$ Faculty of Political Sciences, University of Sarajevo, Bosnia and Herzegovina \\ Correspondence: Andrej Agačević, Glorius Sun School of Business and Management, Donghua University, \\ Shanghai, China.
}

Received: March 29, 2021

Accepted: June 21, 2021

Online Published: June 25, 2021

doi:10.5539/ibr.v14n7p87

URL: https://doi.org/10.5539/ibr.v14n7p87

\begin{abstract}
Tourism economy is severely affected by COVID-19 pandemic, and if it is not adequately handled, the industry will suffer further negative consequences, resulting in economic failure. This study attempts to formulate post-COVID-19 recovery strategies for Destination Management Organizations (DMO) in six ex-Yugoslavia (Ex-Yu) countries. In order to achieve this, firstly, an overview of popularity of tourist sights in the Ex-Yu is given, benchmarking pre-COVID-19 to the current pandemic scenario; secondly, global best case practices of post-COVID-19 recovery strategies in Tourism economy are analyzed, drawing paralles with Ex-Yu countries.

To understand the effect of the global pandemic on the international tourism and in Ex-Yu countries, statistical data from reputable and authentic data sources was collected and analyzed. The research findings prove that effective, long-term strategies are necessary to recover the industry from the negative effects of the pandemic.

This pandemic has left such an impact on this industry, that it will be a challenge to overcome the consequences, some of them for years to stay. Therefore, governments and international organisations, as well as private companies, must establish a long-term plan for the industry so that it does not fail again, as it did in this case, in order to continue on the path of growth. At various stages, methods should be consistent and complementary. Thus, recovery strategies need to respond to challenges in a way that ensures a planned and effective recovery of the industry.
\end{abstract}

Keywords: tourism economy, tourism, best case practices, Ex-Yugoslavia countries, post-COVID-19 recovery

\section{Introduction}

Tourism economy in 2020 was marked with restrictions and travel cancellations, closed companies and agencies, all due to COVID-19 pandemic outbreak. The ongoing crisis, which strongly impacted travel and tourism, still presents an unpredictable outcome. Until 2020, tourism economy has made significant progress and the document „Tourism and the Sustainable Development Goals - Journey to 2030“ provided progressing and future recommendations. Regrettably, it was hard to predict that an outbreak of a disease such as COVID-19 could devastate the global economy and bring global travel to a halt. Now it is essential to work on post-COVID-19 recovery strategies in tourism in order to reduce the negative consequences and speed up the industry's recovery.

The economies in the Ex-Yu countries depend on varying degrees on tourism. On average, its contribution to the region's GDP is over 10\% (RCC, 2020b). The pre-COVID-19 importance of the tourism economy in the six Ex-Yu countries is explored in more detail in Xu \& Agačević (2020) and reported in the Table 1.

In 2018, the global average contribution of Tourism (direct, indirect and induced) to world GDP was $10.4 \%$, according to the WTTC 2018 report (WTTC 2018). If taken as a benchmark for the Ex-Yu countries, it can be observed how, in terms of contribution to GDP, tourism was somewhat relevant for N. Macedonia and Serbia, with room for growth, while BIH and Slovenia followed the global average, and Croatia and Montenegro resulted in being heavily reliant on their tourism economy, with values that double the global average, prior to the pre-COVID-19 pandemic.

Globally, tourism has suffered a deep and radical transformation in 2020. The numbers of visits and profit plunged, but it allowed people to discover new locations within their own countries. New tourist behaviour 
trends emerged, along with new, government-supported, strategies for sustaining the local tourism. Local DMOs have to re-educate themselves on these new emerging trends and strategies in order to surivive and recover in the post-pandemic times.

Table 1. Ex-Yu countries' nominal GDP, total contribution of Travel and Tourism to GDP and yearly growth in EUR million $(1,000,000)$

\begin{tabular}{|c|c|c|c|c|c|c|c|c|}
\hline \multirow[t]{2}{*}{ Ex-Yu country } & \multicolumn{3}{|c|}{ Nominal GDP* } & \multicolumn{3}{|c|}{$\begin{array}{l}\text { Total T\&T contribution to } \\
\text { GDP* }\end{array}$} & \multicolumn{2}{|c|}{$\begin{array}{l}\text { T\&T growth } \\
\text { in } \% \\
\end{array}$} \\
\hline & 2016 & 2017 & 2018 & 2016 & 2017 & 2018 & $16 / 17$ & $17 / 18$ \\
\hline $\mathrm{BIH}$ & 15,332 & 16,628 & 17,374 & 1388 & 1594 & 1694 & 14.84 & 6.27 \\
\hline Croatia & 46,305 & 49,013 & 51,659 & 8635 & 9493 & 10,097 & 9.92 & 6.37 \\
\hline Montenegro & 3954 & 4299 & 4604 & 819 & 889 & 983 & 8.55 & 10.57 \\
\hline N. Macedonia & 9877 & 9992 & 10,699 & 630 & 700 & 772 & 11.11 & 10.29 \\
\hline Serbia & 38,325 & 40,300 & 42,888 & 2399 & 2620 & 2765 & 9.21 & 5.53 \\
\hline Slovenia & 40,357 & 43,278 & 45,948 & 4823 & 5279 & 5699 & 9.46 & 7.96 \\
\hline
\end{tabular}

This article analyses case studies of various strategies used worldwide in order to lower the negative impact of the pandemic on tourism economy. After pinpointing the best practices among these case studies, a set of recommendations for DMOs is offered. The logical thread is that cases of countries successfully coping with the challenges tourism economy have better chances for revival of the industry after the pandemic and should be used as an example for Ex-Yu countries' DMOs.

\section{Methodology and Research Method}

The research method is based on a systematic review of archival primary sources and secondary sources in order to find, collect, reorganize and analyze the data pertinent to the research question. In general, the quantitative data were obtained from archival censuses and analysis conducted by government Statistical Agencies, Ministries of Tourism, World Tourism Organization (UNWTO), World Travel and Tourism Council (WTTC) or Tourism research institutes. For each country, the primary sources containing quantitative data research and statistical analysis conducted by local governments have been preferred as most reliable sources. For Bosnia and Herzegovina, the BiH Agency for Statistics (2021) was consulted as the primary source; for Croatia, the primary sources were the Ministry of Tourism of Republic of Croatia (2021) and Croatian Bureau of Statistics (2021); for Montenegro, the Statistical Office of Montenegro (2021) and the Government of Montenegro (2021) were primary sources; for North Macedonia, the primary sources was the Republic of North Macedonia State Statistical Office (2021); for Slovenia, the Republic of Slovenia Statistical Office (2021) was the primary source; for Serbia, the primary source was the PBC Statistical Office of the Republic of Serbia (2021). The aim of this method was to obtain sufficient data to provide statistically valid and conclusive answers to the proposed research topic.

Concerning the various case studies pertaining to COVID-19 recovery strategies in tourism economy, existing data published by various governmental and non-governmental organizations dealing with tourism was collected and analyzed. Information used in this research was also derived from academic papers, industry white papers and news outlets.

\section{Results}

\subsection{Impact on International Tourism}

International tourism was specifically struck in 2020, and it dropped $70 \%$ in the first eight months of 2020 (UNWTO, 2020). Domestic tourism has mitigated the negative consequences on the local tourist operators and „saved what could be saved" of the season. It is the main driver of the recovery process, but full recovery of the industry is hardly possible without international tourism. According to OECD, recovery to pre-crisis levels is not expected before 2023 (OECD, 2020). Table 2 portrays the economic dependence of different countries on the tourism economy (World Bank, 2020). Countries with a high level of dependence on this industry should urgently work on recovery strategies in order to save their economies. 
Table 2. Tourism Dependency by Tourism contribution to GDP, WTTC 2019 (World Bank, 2020)

\begin{tabular}{|c|c|c|c|c|}
\hline Region & $\begin{array}{c}\text { Severe; }>20 \% \text { GDP in } \\
\text { T\&T }\end{array}$ & $\begin{array}{c}\text { High; } 10-20 \% \text { GDP } \\
\text { in T\&T }\end{array}$ & Medium; $5-9 \%$ GDP in T\&T & $\begin{array}{c}\text { Low; }<5 \% \text { GDP } \\
\text { in T\&T }\end{array}$ \\
\hline $\begin{array}{r}\text { East Asia \& } \\
\text { Pacific }\end{array}$ & $\begin{array}{l}\text { Cambodia, Fiji, Macao } \\
\text { SAR, Philippines, } \\
\text { Vanuatu }\end{array}$ & $\begin{array}{c}\text { Australia, China, } \\
\text { Hong Kong SAR, } \\
\text { Malaysia, New } \\
\text { Zealand, } \\
\text { Singapore, } \\
\text { Solomon Islands, } \\
\text { Tonga, Thailand, } \\
\text { Kiribati }\end{array}$ & $\begin{array}{c}\text { Brunei Darussalam, Indonesia, } \\
\text { Japan, Vietnam, Lao PDR, } \\
\text { Mongolia }\end{array}$ & $\begin{array}{l}\text { Rep. of Korea, } \\
\text { Papua New } \\
\text { Guinea, } \\
\text { Myanmar }\end{array}$ \\
\hline $\begin{array}{r}\text { Europe \& } \\
\text { Central Asia }\end{array}$ & $\begin{array}{l}\text { Albania, Croatia, Georgia, } \\
\text { Greece, Iceland, } \\
\text { Montenegro }\end{array}$ & $\begin{array}{l}\text { Armenia, Austria, } \\
\text { Bulgaria, Cyprus, } \\
\text { Estonia, Italy, } \\
\text { Portugal, Slovenia, } \\
\text { Spain, Turkey }\end{array}$ & $\begin{array}{c}\text { Azerbaijan, Belarus, Bosnia and } \\
\text { Herzegovina, Czech Republic, } \\
\text { Denmark, Finland, France, } \\
\text { Germany, Hungary, Kyrgyz } \\
\text { Republic, Ireland, Kazakhstan, } \\
\text { Latvia, Lithuania, Luxembourg, } \\
\text { Moldova, North Macedonia, } \\
\text { Netherlands, Norway Romania, } \\
\text { Serbia, Slovak Republic, Sweden } \\
\text { Switzerland, Tajikistan, Ukraine, } \\
\text { United Kingdom } \\
\end{array}$ & $\begin{array}{l}\text { Belgium, Ireland, } \\
\text { Poland, Russia, } \\
\text { Uzbekistan }\end{array}$ \\
\hline $\begin{array}{r}\text { Latin } \\
\text { America \& } \\
\text { the } \\
\text { Caribbean }\end{array}$ & $\begin{array}{c}\text { Antigua and Barbuda, } \\
\text { Aruba, Bahamas, } \\
\text { Barbados, Belize, British } \\
\text { Virgin Islands, Cayman } \\
\text { Islands, Dominica, } \\
\text { Grenada, Jamaica, St. } \\
\text { Kitts and Nevis, St. Lucia, } \\
\text { St. Vincent and the } \\
\text { Grenadines }\end{array}$ & $\begin{array}{c}\text { Chile, Costa Rica, } \\
\text { Cuba, Dominican } \\
\text { Republic, El } \\
\text { Salvador, } \\
\text { Honduras, Mexico, } \\
\text { Nicaragua, } \\
\text { Panama, Uruguay }\end{array}$ & $\begin{array}{c}\text { Argentina, Bolivia, Brazil, Ecuador, } \\
\text { Guatemala, Haiti, Peru, Trinidad } \\
\text { and Tobago, Venezuela }\end{array}$ & $\begin{array}{c}\text { Colombia, } \\
\text { Guyana, } \\
\text { Paraguay, Puerto } \\
\text { Rico, Suriname }\end{array}$ \\
\hline $\begin{array}{r}\text { Middle East } \\
\& \text { North } \\
\text { Africa }\end{array}$ & & $\begin{array}{l}\text { Bahrain, Jordan, } \\
\text { Malta, Lebanon, } \\
\text { Morocco, Tunisia, } \\
\text { United Arab } \\
\text { Emirates } \\
\end{array}$ & $\begin{array}{c}\text { Algeria, Egypt Arab Rep. Iran } \\
\text { Islamic Rep., Iraq, Israel, Kuwait, } \\
\text { Oman, Qatar, Saudi Arabia, Syrian } \\
\text { Arab Republic, Yemen Rep. }\end{array}$ & Libya \\
\hline $\begin{array}{r}\text { North } \\
\text { America } \\
\end{array}$ & & Bermuda & Canada, Unites States & \\
\hline South Asia & Maldives & Sri Lanka & India, Nepal, Pakistan & Bangladesh \\
\hline $\begin{array}{r}\text { Sub-Saharan } \\
\text { Africa }\end{array}$ & $\begin{array}{l}\text { Cabo Verde, Sao Tome } \\
\text { and Principe, Seychelles }\end{array}$ & $\begin{array}{c}\text { Botswana, } \\
\text { Comoros, Cote } \\
\text { d'Ivoire, Gambia, } \\
\text { Lesotho, } \\
\text { Madagascar, } \\
\text { Mauritius, } \\
\text { Namibia, Rwanda, } \\
\text { Tanzania }\end{array}$ & $\begin{array}{c}\text { Benin, Cameroon, Central African } \\
\text { Republic, Ethiopia, Ghana, Kenya, } \\
\text { Malawi, Mali, Mozambique, Niger, } \\
\text { Senegal, South Africa, Sudan, } \\
\text { Eswatini, Togo, Uganda, Zambia, } \\
\text { Zimbabwe }\end{array}$ & $\begin{array}{c}\text { Angola, Burkina } \\
\text { Faso, Burundi, } \\
\text { Chad, Congo } \\
\text { Dem. Rep., } \\
\text { Gabon, Guinea, } \\
\text { Nigeria, Sierra } \\
\text { Leone }\end{array}$ \\
\hline
\end{tabular}

The first and the main lesson from COVID-19 pandemic is that governments and other actors need to invest more in preparations for crisis responses. Countries now need comprehensive recovery strategies, which will be focused on sustainability and resilience. Short-term strategies serve as "instant help package" for countries, and they should include actions to deal with challenges such as:

- Maintaining liquidity and viability of tourism businesses, and preventing closures;

- Significant decline in tourist visits;

- Limiting the loss of jobs and skills from the tourism sector;

- Weak consumer confidence and sentiment to travel in domestic and international markets;

- Maximising demand in the domestic market;

- Ensuring that tourism businesses can adapt to social distancing requirements (e.g. through purchase and installation of additional hygiene equipment or installing online booking systems);

- Lack of air capacity due to suspension of air routes; 
- Fall in demand for specific market segments or products (e.g. business travel or cruises);

- Reacting to the effects of possible successive waves of the coronavirus (ETC, 2020).

Once the border restrictions are lifted, it is necessary to harmonise travel safety protocols. Much of the tourism industry's post-COVID-19 success will depend on the robustness, quality and resilience of health and safety protocols that will inevitably govern the industry going forward (Kampel, 2020). This means that countries need to cooperate and exchange the information to harmonise the conditions and encourage the development of tourism. Financial packages will make a short-term solution, but as far as long-term plans are concerned, there is no perfect solution. Long-term recovery measures should focus on business support, developing new marketing campaigns or predicting future demand (ETC, 2020), while empowering domestic tourism as the main driver of the progress. Travellers will be more health-conscious in the future, so health and safety measures will be important if countries want to build the image of their destinations as "responsible tourist attractions". The UNWTO published a strategic guide for a responsible recovery of the tourism sector. It presents six lines of action: public health, social inclusion, biodiversity conservation, climate action, circular economy, as well as governance and finance (ETC, 2020).

According to the European Travel Commission, recovery strategies should include:

- Stimulating demand in the domestic market;

- Stimulating demand from neighbouring markets, easily reachable by road;

- Supporting tourism businesses in adapting to new social distancing and hygiene measures;

- Supporting businesses in sectors that had been particularly affected by public health restrictions or the decline in international visitors, such as the meetings industry, spas and wellness centres;

- Promoting products and experiences associated with nature, health \& wellbeing, outdoor activities;

- Supporting DMOs with strategic guidance and funding in meeting the needs of local businesses and local communities (ETC, 2020).

National Tourist Organisations were interviewed about the differences in their strategic approach to tourism, and the results were presented in the Table 3 (ETC, 2020).

Table 3. Level of agreement with different strategic approaches to tourism in light of the COVID-19 epidemic (ETC, 2020)

\begin{tabular}{|c|c|c|c|c|c|}
\hline Interview question / statement & $\begin{array}{l}\text { Strongly } \\
\text { Agree }\end{array}$ & Agree & Neutral & Disagree & $\begin{array}{l}\text { Strongly } \\
\text { Disagree }\end{array}$ \\
\hline $\begin{array}{r}\text { COVID-19 is a turning point for making tourism in our country } \\
\text { more environmentally friendly }\end{array}$ & $11 \%$ & $47 \%$ & $16 \%$ & $26 \%$ & $0 \%$ \\
\hline $\begin{array}{r}\text { Rebalance of strategic priorities and budgets in favour of } \\
\text { environmentally friendly/community-based initiatives }\end{array}$ & $21 \%$ & $32 \%$ & $37 \%$ & $10 \%$ & $0 \%$ \\
\hline $\begin{array}{r}\begin{array}{r}\text { Restore the levels of tourism arrivals to those seen in recent } \\
\text { years }\end{array} \\
\end{array}$ & $26 \%$ & $37 \%$ & $21 \%$ & $11 \%$ & $5 \%$ \\
\hline $\begin{array}{r}\text { Mass tourism will be essential to achieving the level of growth } \\
\text { seen before }\end{array}$ & $10 \%$ & $0 \%$ & $42 \%$ & $16 \%$ & $32 \%$ \\
\hline $\begin{array}{r}\text { Spend more resources on sustainable areas then traditional } \\
\text { activities such as promotion }\end{array}$ & $32 \%$ & $5 \%$ & $37 \%$ & $21 \%$ & $5 \%$ \\
\hline $\begin{array}{r}\text { Prioritising stimulus measures around certain sustainable } \\
\text { tourism criteria }\end{array}$ & $26 \%$ & $37 \%$ & $26 \%$ & $11 \%$ & $0 \%$ \\
\hline Prioritise local destinations that need visitor spending the most & $26 \%$ & $11 \%$ & $58 \%$ & $5 \%$ & $0 \%$ \\
\hline $\begin{array}{r}\text { Reduce / withdraw funding from sectors / businesses that are } \\
\text { responsible for high carbon emissions }\end{array}$ & $32 \%$ & $0 \%$ & $42 \%$ & $16 \%$ & $11 \%$ \\
\hline $\begin{array}{r}\text { Work with relevant stakeholders to find new ways to reduce the } \\
\text { negative impacts of tourism }\end{array}$ & $32 \%$ & $53 \%$ & $5 \%$ & $5 \%$ & $5 \%$ \\
\hline
\end{tabular}

\subsection{Tourism in Ex-Yugoslavia Countries}

In the countries of Ex-Yugoslavia, travel restrictions were imposed and all countries had different policies. It led to an increase in "staycations" and development of local tourism. Inbound Tourism directly contributes $15 \%$ to overall GDP of the Western Balkans, and it supports a multitude of jobs and industries, accounting for around 550000 jobs in 2019 (RCC, 2020a). Consequentially, in line with global trends, there was an increase in "staycations" and development of local tourism, meaning some locations that were not highly known or popular 
destinations attracted higher numbers of tourists.

The following tables present selected locations in Ex-Yu countries, some highly known (or "popular") and others less so, with the summary of the impact that the new COVID-19 tourism trends had on their "popularity", and the travel restrictions these countries put in place.

Table 4. BiH, travel restrictions, selected tourist destinations pre-COVID-19 popularity and impact of pandemic on visits

\begin{tabular}{|c|c|}
\hline Country & Bosnia and Herzegovina $(\mathrm{BiH})$ \\
\hline $\begin{array}{r}\text { Travel restrictions } \\
\text { in place }\end{array}$ & $\begin{array}{l}\text { The borders of } \mathrm{BiH} \text { are open for foreigners given that they provide a negative PCR test no older than } 48 \\
\text { hours, whereas citizens of Croatia, Montenegro and Serbia are allowed to enter BiH without any testing, } \\
\text { provided that they are entering directly from one of these countries (OECD, 2021) }\end{array}$ \\
\hline Location & Sarajevo, the Capital of $\mathrm{BiH}$; a globally fairly well-known destination \\
\hline $\begin{array}{r}\text { Pre-COVID-19 } \\
\text { popularity }\end{array}$ & $\begin{array}{l}\text { Very popular: from January to July } 2019 \text {, the number of tourist arrivals amounted to } 358,906 \text { and } \\
\text { recorded an increase of } 15.7 \% \text {, compared to the same period last year. In the period from January to } \\
\text { July } 2019 \text {, the total number of tourist nights is a record } 786,203 \text { and records an increase of } 30.2 \% \\
\text { compared to the same period (Sarajevo.ba, 2019). }\end{array}$ \\
\hline $\begin{array}{l}\text { Visits during the } \\
\text { pandemic }\end{array}$ & $\begin{array}{l}\text { Highly under-visited: the } 2020 \text { season can be considered a failure. Reservations of domestic and foreign } \\
\text { tourists were cancelled. A total of } 81.1 \% \text { of respondents reported cancellations ranging from } 61 \% \text { to } \\
100 \% \text { (AlJazeera, 2020). }\end{array}$ \\
\hline Location & Neum, a fairly popular summer location, sharing the Croatian coastline \\
\hline $\begin{array}{r}\text { Pre-COVID-19 } \\
\text { popularity }\end{array}$ & $\begin{array}{l}\text { Average popularity: especially when compared to the neighbouring locations in Croatia. It is a small } \\
\text { coastal town with the capacity of around } 7000 \text { beds, and has gained popularity in recent years (VMO, } \\
\text { n.a). }\end{array}$ \\
\hline $\begin{array}{l}\text { Visits during the } \\
\text { pandemic }\end{array}$ & $\begin{array}{l}\text { Highly visited: closed borders with Croatia and Montenegro resulted in profit for Neum, the only } \\
\text { coastal city in BiH. Besides the locals, it became a popular location for tourists from Serbia } \\
\text { (Dimitrijević, 2020). }\end{array}$ \\
\hline Location & Jahorina, mountain where Winter Olympic Games 1984 were held \\
\hline $\begin{array}{r}\text { Pre-COVID-19 } \\
\text { popularity }\end{array}$ & $\begin{array}{l}\text { Growing Popularity: gained popularity in recent years. In 2018, a record number of almost } 175,000 \\
\text { skiers was recorded; revenues from ticket sales reached more than EUR } 2.5 \text { million and exceeded } \\
\text { revenues from the entire last season by } 75 \% \text {. }\end{array}$ \\
\hline $\begin{array}{l}\text { Visits during the } \\
\text { pandemic }\end{array}$ & $\begin{array}{l}\text { Highly visited: as many EU ski resorts remained closed due to the COVID- } 19 \text { pandemic, tourists who } \\
\text { had previously gone skiing to France, Italy or Austria flocked to Jahorina, which currently has } \\
\text { significantly better booking than the previous season. }\end{array}$ \\
\hline
\end{tabular}

Table 5. Croatia, travel restrictions, selected tourist destinations pre-COVID-19 popularity and impact of pandemic on visits

\begin{tabular}{|c|c|}
\hline Country & Croatia \\
\hline $\begin{array}{r}\text { Travel restrictions } \\
\text { in place }\end{array}$ & $\begin{array}{l}\text { Partially open for foreigners and foreign tourists, following traditional seasonal trends: open during } \\
\text { high/summer season and closed during low/winter season. }\end{array}$ \\
\hline Location & Dubrovnik; ancient city-state; a globally highly known destination \\
\hline $\begin{array}{r}\text { Pre-COVID-19 } \\
\text { popularity }\end{array}$ & $\begin{array}{l}\text { Highly popular: in } 2019 \text {, about one and a half million more tourists visited Croatia than in 2018, } \\
\text { recorded as a } 5 \% \text { increase in tourist arrivals. Dubrovnik is the most popular location in the country and } \\
\text { the most visited city (Ministry of Tourism of Republic of Croatia, 2019). }\end{array}$ \\
\hline $\begin{array}{r}\text { Visits during the } \\
\text { pandemic }\end{array}$ & $\begin{array}{l}\text { Strongly under-visited: there was a drop in arrivals and overnight stays of as much as } 66 \% \text { (HrTurizam, } \\
2020 \text { ). }\end{array}$ \\
\hline Location & Plitvice Lakes National Park, globally known destination \\
\hline $\begin{array}{r}\text { Pre-COVID-19 } \\
\text { popularity }\end{array}$ & $\begin{array}{l}\text { Constant popularity: in } 2019 \text {, there was no excessive tourist influx in the most famous national park. In } \\
\text { the first half of the year, } 625,000 \text { tickets were sold, the same as last year's first half (Kovačević, 2019). }\end{array}$ \\
\hline $\begin{array}{l}\text { Visits during the } \\
\text { pandemic }\end{array}$ & $\begin{array}{l}\text { Highly visited: from May } 11 \text { to } 24 \text {, the Park registered more than } 45,000 \text { visitors, a record number. The } \\
\text { maximum attendance in accordance with the prescribed measures and capacities was recorded (Prodan, } \\
2020 \text { ) }\end{array}$ \\
\hline
\end{tabular}


Table 6. Montenegro, travel restrictions, selected tourist destinations pre-COVID-19 popularity and impact of pandemic on visits

\begin{tabular}{|c|c|}
\hline Country & Montenegro \\
\hline $\begin{array}{r}\text { Travel restrictions } \\
\text { in place }\end{array}$ & $\begin{array}{l}\text { Open for citizens, partially open for foreigners and tourism. Foreign nationals seeking to enter } \\
\text { Montenegro need a negative PCR test for the SARS-CoV-2 virus taken within the previous } 72 \text { hours. }\end{array}$ \\
\hline Location & Coastline; a well-known summer destination on Mediterranean coast \\
\hline $\begin{array}{r}\text { Pre-COVID-19 } \\
\text { popularity }\end{array}$ & $\begin{array}{l}\text { Highly popular: Montenegro is one of the fastest-growing tourist destinations, it has 3rd world ranking } \\
\text { by the tourism growth in the } 2018 \text { forecast (WTTC, } 2018 \text { a) }\end{array}$ \\
\hline $\begin{array}{l}\text { Visits during the } \\
\text { pandemic }\end{array}$ & $\begin{array}{l}\text { Under-visited: revenues of the tourism industry in July } 2020 \text { in Montenegro amounted to roughly EUR } \\
10 \text { million, while same month last year it amounted to EUR } 280 \text { million, which is a decrease of about } \\
96 \% \text {. In July } 2019 \text {, all types of accommodation registered } 3.7 \text { million overnight stays, while } 2020 \\
\text { brought about } 200 \text { thousand. }\end{array}$ \\
\hline
\end{tabular}

Table 7. North Macedonia, travel restrictions, selected tourist destinations pre-COVID-19 popularity and impact of pandemic on visits

\begin{aligned} & \hline Country North Macedonia \\ & \hline Travel restrictions $\begin{array}{l}\text { The Republic of North Macedonia has officially reopened for international tourism on July 1st, 2020 } \\ \text { ind place now allowing tourists from all countries, restriction free. In the first part of 2020, strict measures } \\ \text { discouraged tourists }\end{array} \\ &$\hline $\begin{array}{r}\text { Location } \\ \text { Pre-COVID-19 }\end{array} \begin{array}{l}\text { Due to country's small size, mostly the Capital and Ohrid Lake } \\ \text { Stable Popularity: in 2019, North Macedonia received 1,184,963 tourist arrivals out of which 757,593 } \\ \text { foreign. In recent years, it experiences a regular increase of visitors (MAKSTAT, 2019a) }\end{array} \\ &$ Visits during the $\begin{array}{l}\text { Somewhat visited: guidebook company Lonely Planet has named North Macedonia as one of the } \\ \text { pandemic } \\ \text { world's best tourist destinations in 2020 due to its "untouched natural wonders"(Marusic, 2019). } \\ \text { However, the number of tourists in North Macedonia decreased by 18.3\% year-on-year in the first } \\ \text { quarter of 2020 (MAKSTAT, 2021) }\end{array} \\ &$\hline\end{aligned}

Table 8. Serbia, travel restrictions, selected tourist destinations pre-COVID-19 popularity and impact of pandemic on visits

\begin{tabular}{|c|c|}
\hline Country & erbia \\
\hline $\begin{array}{r}\text { Travel restrictions } \\
\text { in place }\end{array}$ & $\begin{array}{l}\text { pen for local tourists; partially open for foreigners and foreign tourists. Country-wide restriction } \\
\text { easures. }\end{array}$ \\
\hline Location & Belgrade the Capital of Serbia; a well-known destination \\
\hline $\begin{array}{r}\text { Pre-COVII } \\
\text { popul }\end{array}$ & $\begin{array}{l}\text { Highly popular: the number of tourists in Belgrade in the period January-November } 2019 \text { was } \\
1,107,694 \text {. Out of that, there were } 943,280 \text { foreign tourists (RZSS, 2020). }\end{array}$ \\
\hline $\begin{array}{l}\text { Visits durin } \\
\text { pand }\end{array}$ & $\begin{array}{l}\text { Under visited: due to strict restriction measures, during } 2020 \text {, a total of } 1,820,021 \text { tourists stayed in } \\
\text { Serbia, } 51 \% \text { less than in } 2019 \text {. In the same period, foreign tourists realized the most overnight stays in } \\
\text { Belgrade, } 576,687 \text { overnight stays, or } 73 \% \text { less than in the period January-December } 2019 \text {. (Danas.rs, } \\
2021 \text { ). }\end{array}$ \\
\hline Loc & Zlatib \\
\hline $\begin{array}{r}\text { Pre-COVID-19 } \\
\text { popularity }\end{array}$ & $\begin{array}{l}\text { Popular: The index of tourist visits and overnight stays on Zlatibor was growing. In the first five } \\
\text { months of } 2019 \text {, registered } 8.7 \% \text { more arrivals than in the same period in } 2018 \text {, while the number of } \\
\text { tourists who visited Zlatibor in May was higher by as much as } 14.6 \% \text { compared to last year (Pesic, } \\
\text { 2019). }\end{array}$ \\
\hline $\begin{array}{l}\text { Visits durin } \\
\text { pand }\end{array}$ & $\begin{array}{l}\text { Highly visited: Zlatibor was the most visited mountain in Serbia in the first eight months of 2020, with } \\
491,000 \text { overnight stays. Greater popularity is expected in the winter season 2020/2021. }\end{array}$ \\
\hline
\end{tabular}

Table 9. Slovenia, travel restrictions, selected tourist destinations pre-COVID-19 popularity and impact of pandemic on visits

\begin{aligned} & \hline Country Slovenia \\ & \hline $\begin{array}{r}\text { Travel restrictions } \\ \text { in place }\end{array} \begin{array}{l}\text { Entry to Slovenia is permitted with no restrictions and quarantine from countries that are on the green or } \\ \text { orange list with no border crossing limitations. People coming from countries or territories on the red } \\ \text { list are subject to 10-day quarantine unless they submit a negative COVID-19 test. }\end{array} \\ &$\hline $\begin{array}{r}\text { Location } \\ \text { Pre-COVID-19 }\end{array} \begin{array}{l}\text { Small size and mostly Natural locations narrow the case study } \\ \text { popularity } \\ \text { arrivals and 0,5\% more overnight stays than in 2018 (Republic of Slovenia Statistical Office, 2019) }\end{array} \\ &$ Visits during the $\begin{array}{l}\text { Somewhat salvaged: In July 2020 tourist accommodation establishments recorded a rapid growth in } \\ \text { pandemic } \\ \text { tourist overnight stays compared to previous months of 2020; while domestic tourists generated almost } \\ 1.4 \text { million overnight stays, foreign tourists generated slightly over 670,000. Still, tourism in 2020 fell } \\ \text { for about 50\%. (Republic of Slovenia Statistical Office, 2021) }\end{array} \\ &$\hline\end{aligned}




\subsection{Ex-Yu Countries Tourist Overnight Stays: Global Pandemic Data}

Concerning the Ex-Yu countries, several of them had lockdowns in different months, so while the overall data trends follow the global fall of inbound tourists, individual months are directly conditioned by lockdown measures. Also, regarding domestic tourists, one would expect the trends to follow other countries, but, unfortunately, only several countries had a proactive campaign to promote local destinations, other countries are a reflection of a more "organic", self-generated recovery, thanks to local freelancers and small local tourist agencies that quickly adapted to the new market conditions. While there are considerable difficulties in collecting data during the pandemic, the relevant ministries and statistical bureaus have published some reports, mostly until November 2020. The data concerning domestic and foreign visitors, or overnight stays, depending on availability, has been reported here, with the purpose of illustrating the impact that COVID-19 pandemic has on Ex-Yu countries tourism trends. Some graphs are extracted from official reports that offered them while others have been pieced together from monthly data in statistical databases.

The following graph on 2019-2020 tourist overnight stays month-by-month comparison (Figure 1.) for BiH has been constructed based on data obtained from Bosnia and Herzegovina Agency for Statistic report (2021a).

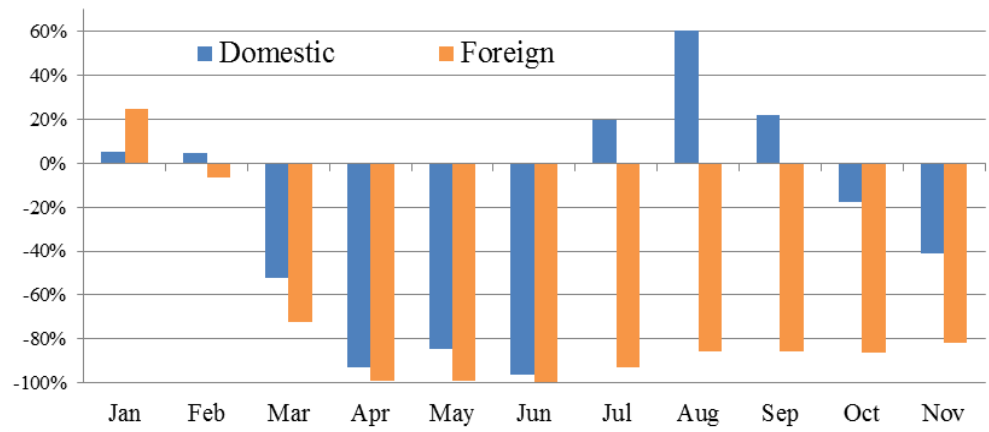

Figure 1. BiH 2019-2020 overnight stays fluctuation, month by month, in percentages

Observing the foreign overnight visitors trend, an almost complete halt of visitors is noted in April, May and June, when major lockdowns were in place across Europe, including BiH. The numbers picked up a little during the summer months, with first openings, but barely reached 10-15\% of 2019 values. Domestic overnight stays, on the other hand, while following the total local lockdown trend, did pick up greatly during the summer, after the lockdown was lifted, outperforming 2019 by 60\% in August. Unfortunately, it must be noted that there was no recovery mechanism or promotional plans by the Tourism boards or any involvement and merit by the government. These positive growth numbers can be explained by 2 main factors: 1) spontaneous "stayvacations", especially given BIH's small population density and availability of natural destinations, minimizing Health \& Safety risks and self-reliant freelancer guides maximizing their effort to survive the economic hardship brought by the pandemic and being flexible to last minute, small number, out-door tours; 2) BiH locals prefer to travel abroad during the summer, therefore the lockdown accentuated the gap with 2019. The autumn period is not favourable for outdoor activities except for passionate hikers and mountaineers, therefore the strong reduction in domestic overnight stays is justified.

It is clear that Croatia is very heavily dependent on foreign tourism and majority of population along the coastline lives of tourism. Croatian Tourism Bureau is proactive and there are constant promotional campaigns. Croatia also had a moderate success in promoting local tourism in 2020. According to the Tourism Board data, Croatia achieved 7.8 million arrivals in 2020, roughly $37 \%$ compared to 2019 , and 54.4 million overnight stays, around $50 \%$ of 2019 's total. Foreign tourists were 43.1 million (45\% compared to 2019) while domestic tourists accounted for 11.3 million overnight stays or $82 \%$ compared to 2019. The director of Croatian Tourist Bureau, Kristjan Staničić, in an interview, attributed this success to the "Croatia full of Life" and "Croatia full of Magic" campaigns and announced a new campaign for 2021: "Croatia Full of New Beginnings". Croatia's 2019-2020 tourist overnight stays month-by-month comparison graph has been extracted from Croatian National Tourist Board (2021) and proposed here (Figure 2). 


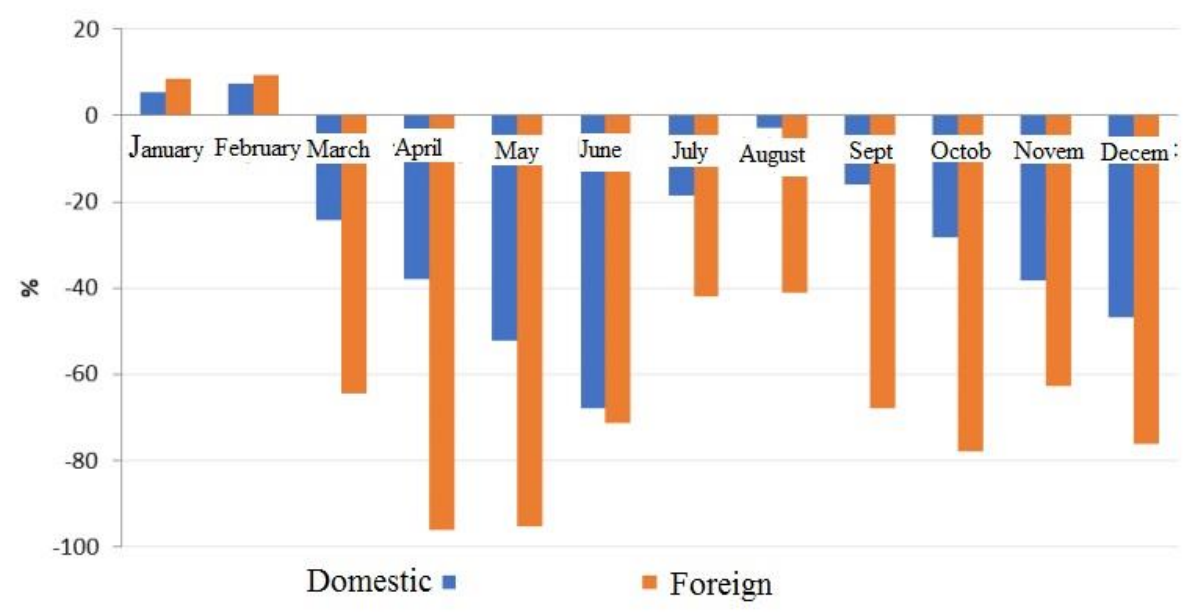

Figure 2. Croatia 2019-2020 overnight stays fluctuation, month by month, in percentages

From the graph, we can see how the domestic overnight stays almost reached previous years' values, while foreign overnight stays plummeted heavily. By considering data from previous parts and understanding the volumes and significance of foreign tourists for Croatia, these results actually constitute quite a success in curbing the damage brought by the April-May lockdowns. It would not be wrong to affirm that Croatia's $60 \%$ of 2019's August 25 million visitors still equals more than 10 times the total of other five Ex-Yu countries. Since Croatia is mostly a summer destination, and with new travel restrictions in place, the reduction of foreign overnight stays is quite expected. Domestic overnight stays trend is also logical. While it follows the lockdown curve, the percentages indicate the local population was practicing "staycations. The lack of summer spike, which is found in $\mathrm{BiH}$, for example, is easily explained by the fact that locals tend to stay put in summer given their heavy reliance on employment in tourism economy. In fact, the peak high season values are almost identical to 2019. Overall, considering the regional pandemic trends and several lockdowns, Croatia's effort in targeting both locals and foreigners has been quite fruitful.

The Figure 3. shows Montenegro 2019-2020 tourist overnight stays.

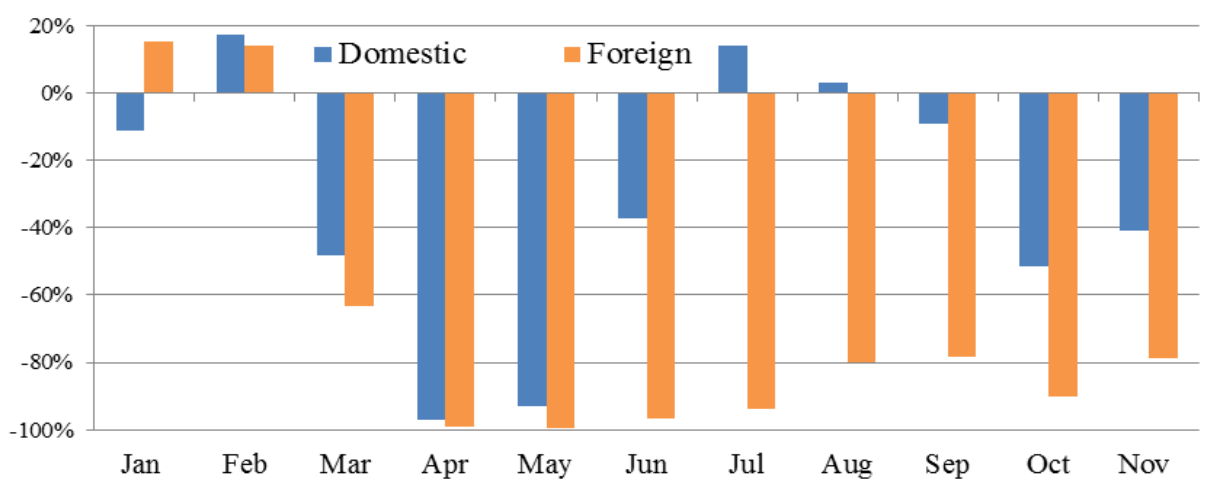

Figure 3. Montenegro 2019-2020 overnight stays fluctuation, month by month, in percentages

The month-by-month comparison has been constructed based on data obtained from Montenegro Statistical Office monthly reports (MONSTAT, 2021). Montenegro has had quite a critical scenario during the April-May lockdown, since the pandemic was not handled very well by the government. There was no particular effort to promote tourism abroad, and the slight improvements during summer are simply the reflection of the fact that Montenegro did not require any sort of COVID-19 testing of tourists from neighbouring countries. Since Montenegro is mainly a summer vacation destination and it shares the coastline with Croatia, it makes sense that the trends of two countries are somewhat similar in domestic overnight stays, since in summer the local population is mostly involved in tourism economy. Also, Montenegro's total population in 2019 was 622,140, so that $10 \%$ increase in 2020 August domestic overnight stays actually translates as several thousand visitors margin. 
As the case with Croatia, the overall reduction in both domestic and foreign tourist in autumn was to be expected.

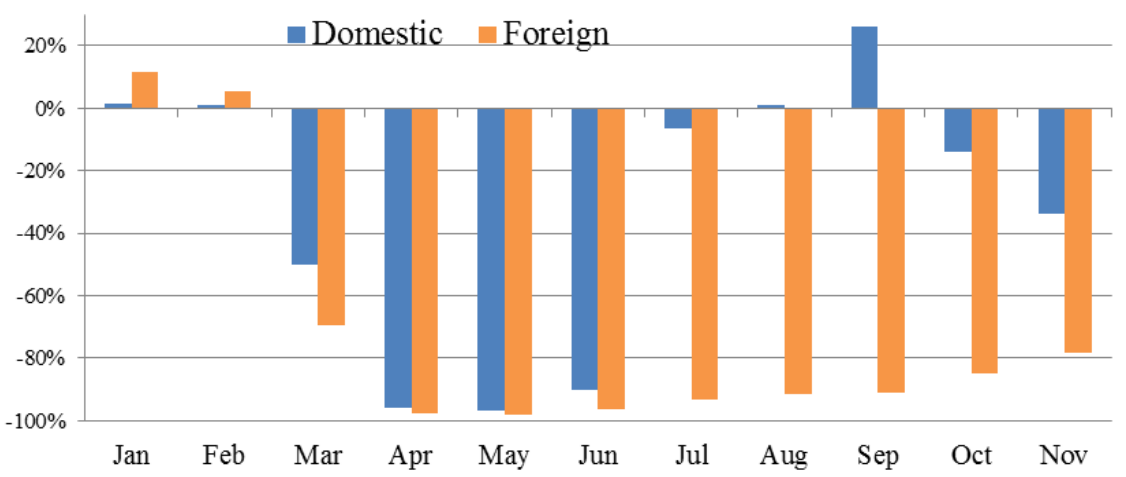

Figure 4. N. Macedonia 2019-2020 overnight stays fluctuation, month by month, in percentages

N. Macedonia's graph on 2019-2020 tourists overnight stays comparison, month-by-month (Figure 4.), has been constructed based on data obtained from North Macedonia State Statistical Office (MAKSTAT, 2021). Observing the above graph, it is clear how N. Macedonia has suffered the April-May lockdown even more than other countries. In fact, N. Macedonia's June has also seen only 5-10\% of 2019's overnight stays. Since it is not a very popular destination, and there were no particular programs to promote the tourism abroad, foreign overnight have remained at all-time record lows. Interestingly enough, the domestic tourism picked up during summer, much similar to BiH scenario.

On one side, N. Macedonia has natural and outdoor tourism resources and population density similarities to BiH; on other side, in June, N. Macedonia's government did provide stimuli to local tourism. The Minister of Economy, Kreshnik Bekteshi, announced the launch of the platform "Home is home," with the list of citizens who can receive vouchers to encourage domestic tourism (Sloboden Pecat, 2020). To aid the hotel industry, activities related to trainings, conferences, and seminars in domestic hotels were encouraged. Events and conferences were co-financed by 50 percent of the costs or up to 30,000 Macedonian Denar (about 549 U.S. dollars) per applicant. Overall, N. Macedonia has managed to mitigate the impact to its tourism economy in areas where it had some control, i.e. domestic tourists, while the situation with foreign tourist remained critical across the entire 2020, picking up slowly towards the end of the year, since the lockdown measures eased.

Serbia 2019-2020 tourist overnight stays data (Figure 5.) is obtained from Statistical Office of the Republic of Serbia (PBC, 2021).

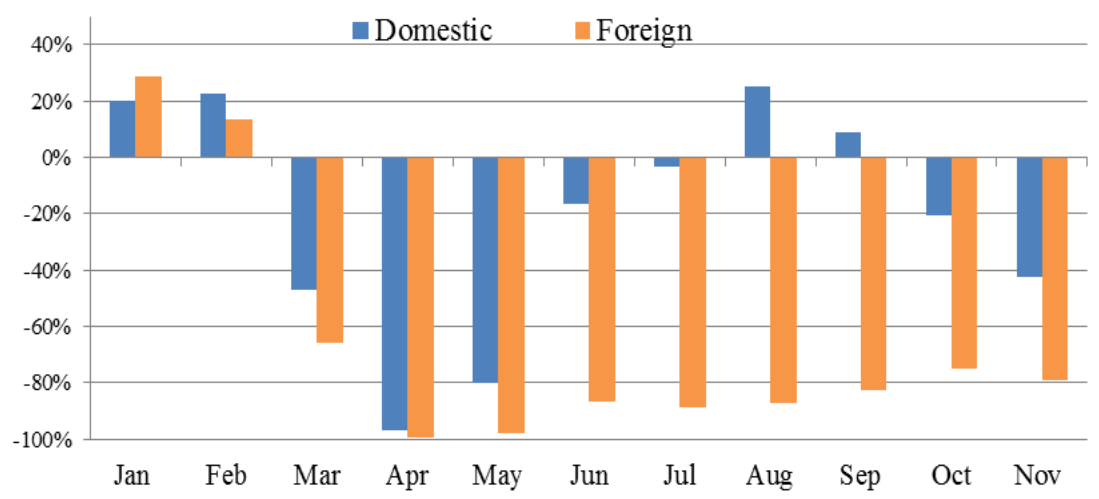

Figure 5. Serbia 2019-2020 overnight stays fluctuation, month by month, in percentages

Serbia's trends are quite similar to the ones of its neighbouring BiH, Montenegro and N. Macedonia. April-May lockdown has taken its toll, with plummeting numbers in both foreign and domestic overnight stays. The foreign tourists numbers hardly improve, averaging a negative growth of $80 \%$ compared to 2019 . Serbia is not a popular summer destination, so this kind of scenario was to be expected without some degree of heavy investment, 
promotion and government support for travel and tourism marketing campaigns, as was the case in Croatia. Similar to its neighbours, the domestic numbers go up once the local lockdown is lifted, with summer values that see a positive growth, again for reasons similar to $\mathrm{BiH}$ : Serbia is not really a popular summer destination and its population usually travels abroad; with borders closed, the travellers that would travel abroad are forced to travel locally, accentuating the gap with previous year. Director of Tourism Association of Serbia, Marija Labović stated that villages, mountains and spa destinations were highly popular, resulting in high number of domestic visitors, with some locations being fully booked and added that focus on domestic tourists as TTG is vital for the next year (RTS, 2020).

Slovenia's data on 2019-2020 tourist overnight stays (Figure 6.) has been obtained from Republic of Slovenia Statistical Office (2021).

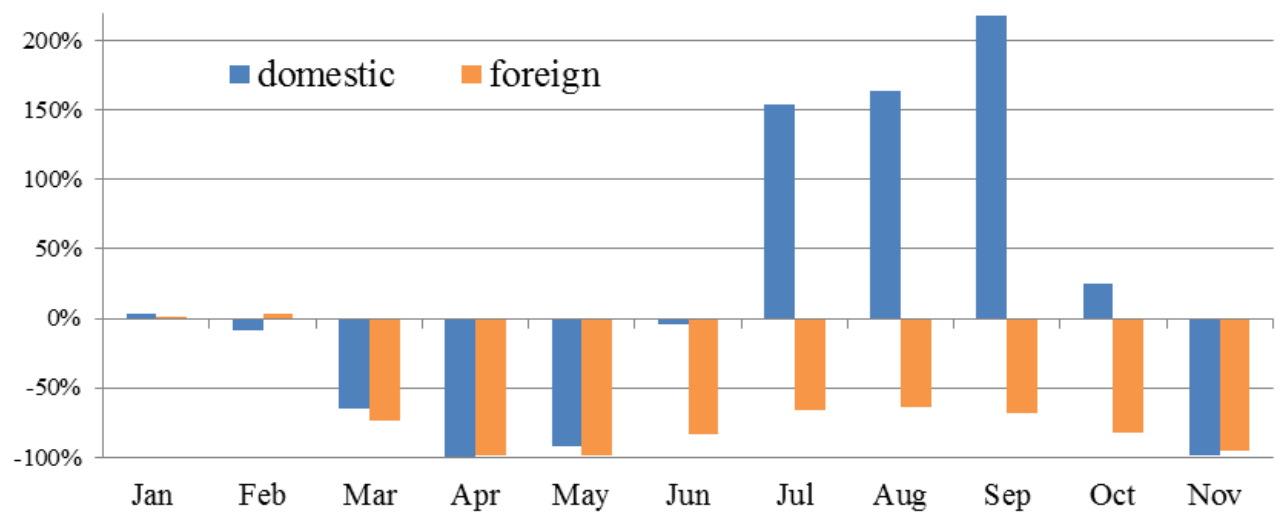

Figure 6. Slovenia 2019-2020 overnight stays fluctuation, month by month, in percentages

Slovenia has a similar trend to Croatia's in regards to foreign overnight stays trend. The total lockdown in April-May all but deleted inbound tourism. Summer values have picked up, reaching values of roughly $40 \%$ of 2019. This is also relatable to Croatia, given the two countries' vicinity and Slovenia's geographical position that favours visitors from central EU. As for the surprising spike in domestic overnight stays after the lockdown, it is probably the merit of strong promotional campaigns and stimuli towards the local population. Slovenia, similarly to Croatia, has a developed tourism economy with solid content and high-quality attractions.

On 14 May 2020, the Slovenian Tourist Board (2020) presented the Slovenia-wide promotional campaign "The Time is now. My Slovenia", inviting Slovenians to spend a short or long holiday at their nearest destination in Slovenia, while discovering its hidden nooks and crannies and experiencing exceptional adventures and the hospitality of domestic tourism service providers. The campaign is being carried out in cooperation with many partners: the tourism industry, destinations, key institutions of Slovenian tourism, product associations, ambassadors and influential individuals, the media and other institutions.

Government stimulus was also an important factor, as Slovenia rolled out seven packages in 2020. In December, Economy Minister Zdravko Počivalšek stated that the way forward will be outlined in the 2020-2023 recovery plan and that shareholders are also coming up with projects to draw on EU funds, concluding that the sector will return to record-breaking results (STA, 2020).

Among ex-Yugoslavia countries the case of Slovenia can be considered the most fitting one, as it checks all steps, from acting within travel constraints brought about by COVID-19 pandemic, identifying suitable, less known locations and attractions for potential domestic tourists, while setting up a branding campaign and coordinating with all relevant actors and interest holders on the territory.

From the above tables, it can be observed how across all Ex-Yu countries there, all of the well-known destinations suffered to some degree, because of the pandemic; some locations managed to "salvage" a part of high season, either thanks to government stimuli or to organic effect of "stayvacations", or the combination of both. Nevertheless, it is clear how the level of pre-COVID-19 popularity of a location does not play a major role in the pandemic scenario. Therefore, new approaches are necessary in order for DMOs to adapt to the post-pandemic scenarios, which will surely contain elements of the new tourist trends as the "new normal".

\subsection{International Best Case Practices}

According to "Interreg Europe" (2020) report, the Province of Teruel (Aragón, Spain) revised its "Strategy for 
sustainable tourism" in April 2020, to comply with the new reality imposed by the coronavirus outbreak. The Province used all flexibilities provided by its budget and scrapped activities that would not be compatible with prevention measures, offering a rather quick and effective response to mitigate the effect on local tourism. The revised strategy included: storytelling - for increasing the attractiveness of the Province as a safe destination; enhanced promotion of the El Cid cultural route - a usually less beaten track; marketing of sustainable locally sourced products; discounts of $30 €$ on 3,000 overnight stays - to incentivise proximity tourism; measures to 'put on the map' villages with less than 500 inhabitants - normally overlooked by tourist flows; partnership with restaurants and local media outlets. Provisional data indicate that, despite the pandemic, small hotels and rural houses scored good reservation rates in the first part of the touristic season. The approach adopted by local policymakers helped their businesses to cope with the new circumstances.

Tourism New Zealand (2020) has launched a "Do Something New, New Zealand!" campaign in May, costing AUD 500.000. Focus is on "staycation" deals, discounted nature experiences and incentives to visit local attractions. With New Zealand's border closed to nearly all foreign arrivals since March, sites and attractions typically popular with first-time visitors such as Franz Josef Glacier and Milford Sound have recorded a huge decline in visitors as international arrivals fell from -99\% to 100\% in April (Ministry of Business, Innovation and Employment, 2020). Regions with driving distance of major cities - including Northland, Coromandel and the top of the South Island - have seen high growth as New Zealanders responded to the government's call to support the struggling tourism industry and "see your own back yard". The "Great Walks" were also proving popular over the summer, with the occupancy rates of the Department of Conservation-managed huts for hikers' overnight stays along the trails averaging $83 \%$ full, and Tōtaranui becoming the country's most popular campsite. More than 42,000 overnight stays had been booked from early December to the end of February. Tourism NZ has released scenario modelling of the recovery of Aotearoa's tourism industry which projects an increase of $118 \%$ in locals travelling around the country in January 2021, compared to 2020.

In Singapore, to help cushion the blow to companies and avoid massive job losses in the tourism sector, the Singapore Tourism Board (STB), Enterprise Singapore and Sentosa Development Corporation teamed up with industry to encourage locals to rediscover Singapore, launching a nine month-long domestic tourism campaign in June, costing USD 45 million (STB, 2020). The main points are: partnering with local communities to help locals discover hidden gems; curating precinct itineraries to create authentic experiences for locals; collaborating with hotels, tour operators, attractions and precincts to develop quality experiences and attractive promotions. Precincts will be packaged as mini-holiday destinations, where locals can embark on a "Singapoliday" to enjoy the many experiences and promotions within.

At the same time, other countries are opening their borders and promoting safe tourism. The United Arab Emirates managed to create a sustainable strategy for tourism and its gradual recovery. In summer 2020, it opened its borders for international tourists, while maintaining high safety and health standards (Elborno, 2020). The government set up the Emirates Tourism Council, which will create a unified domestic recovery strategy for tourism economy. They launched the "World's Coolest Winter" the 45-day campaign, which aims to attract tourists to explore attractions in the country at the beginning of 2021 (Emirates News Agency, 2020).

Turkey is among the countries which opened their borders early. There are specific hygiene measures, so plenty of tourists choose Turkey for their vacation. According to the OECD, the following measures are in place in Turkey to support tourism businesses in the COVID-19 crisis:

- Bank loans are provided for reimbursement of advance payments for early bookings.

- Social Security payments are postponed for 6 months.

- Ministry-certified travel agencies are allowed to work online without opening their workplaces, until the end of April.

- The debts of tourism facilities located on public lands were delayed for 6 months.

- The activities of day-trip excursion boats, certified by the Ministry of Culture and Tourism, were stopped.

- The schedule to submit the relevant documents to obtain a Certificate from the Ministry of Culture and Tourism to open service and tourism establishments is frozen for tourism investments located on public lands with a due date of 1 April 2020.

- Swift bank loans offered for small-scale tourism agencies without need of repayment for 6 months.

- The accommodation tax in hotels and tourism facilities is waived until November 2020 (OECD). 
Such measures boosted the economy, helped the recovery of the industry and left a confident impression on tourists, who decided that Turkey is a responsible tourist attraction. This example can be applied in other countries whose economy is highly dependent on tourism economy.

\section{Discussion}

The previous data shows a clear picture of the tourism industry in Ex-Yu countries in the period when they were affected by the COVID-19 pandemic, as well as examples of countries that have found functional mechanisms to help their economies while coping with the virus. This proves the hypothesis that effective strategies are necessary to recover from the negative effects of the pandemic on tourism economy. Currently, traveling is becoming increasingly localized and complicated, so international organizations suggest developing long-term plans for the industry's recovery. Although it will take a long time for the industry to return to pre-COVID-19 situation, short-term strategies do not provide enough support for the economy, but they should not be completely neglected. They can serve as "first aid" until long-term strategies are developed.

The results of a research done by Fotiadis, Polyzos \& Huan, give predictions on the future outcome for the industry. "In terms of policy, our predictions suggest that the crisis is far from over in the tourism sector. Without a medical solution to the pandemic, tourists will be reluctant to travel, despite the protective measures taken by transport and hospitality companies. The current tourist season should be counted as an almost total loss for the industry, since the drop for the current year currently exceeds $98 \%$. Our forecasts for the coming months show a drop of around 50\% in December 2020, compared to the previous December, while predictions in some of our scenarios for June 2021 are even graver” (Fotiadis, Polyzos \& Huan, 2021). „Going forward, it would be crucial for the governments and marketing firms to undertake research to analyse the effects of the current catastrophe on the industry (Min et al., 2011). This research too makes a case for raising awareness to view this pandemic as a wakeup call to prepare for the aftereffects. Going forward other highlighted aspects in the current study such as change in travel and dining habits, careful spending, need of adaptability, market research, leadership roles, population issues would be critical in preparing industry and stakeholders" (Kaushal \& Srivastava, 2021). After the pandemic, businesses will undoubtedly rethink their business strategies in light of the losses experienced and potential market conditions. And why are these changes necessary? In order to be able to continue in the direction of development, governmental and international organizations, as well as private businesses, need to make a sustainable strategy towards industry so that it does not collapse again, as in this case. Strategies at different levels should be coherent and complementary. This opinion is supported by Fotiadis, Polyzos \& Huan (2021): ,The persistence of this crisis, as signified by our predictions, suggests that firms in the tourism sector will need to re-evaluate their business models to incorporate for the reduced demand and increased costs. The new status quo, which will linger for at least a year based on our predictions, suggests that profitability in the industry needs to be re-evaluated and new tourist products may need to emerge, reshaping the sector. These changes may be temporary or may persist even after the crisis has passed. As a response, authorities will need to subsidize the protective measures they propose in order to support tourism, especially in countries where tourism revenue contributes highly to GDP. Government subsidies on these measures will also help confirm that the measures will be implemented as they are planned by medical professionals, since poor or scanty implementation can have the same detrimental effects as no implementation, with the added cost of false security. It is important that the tourist sector embraces medical guidelines as they represent the shortest path out of the current crisis." The proliferation of COVID-19-related tourism offers a range of opportunities to research and better understand this phenomenon in new and different ecosystems, stakeholders, and circumstances. In essence, a hitherto unseen approach is needed that gives industry researchers the freedom to propose unconventional solutions, given that the traditional approach proved as dysfunctional in a crisis situation such as COVID-19 pandemic. This serves as a wake-up call, which requires completely creative approaches, which are especially lacking in Ex-Yu countries.

Best-case practice examples show that they have adapted to the situation on the ground. Various factors influence tourists to choose locations they consider safe: there is a high level of hygiene, an easy way to enter the country and precise instructions on the epidemiological situation. Spain, New Zealand, Singapore, the UAE and Turkey are some examples of countries that have responded promptly to the crisis and found a strategy that will nevertheless ensure a certain level of success for the tourism industry in the pandemic times. It is clear that these states will have an easier long-term recovery.

On the other hand, Ex-Yu countries that have localized tourism to predominantly domestic ones will face the challenge of becoming internationally attractive destinations again. Each country's 2019-2020 domestic and foreign tourists growth data is presented in a series of graphs. All six countries experienced negative growth in both domestic and foreign tourist at the beginning of the COVID-19 outbreak in March, followed by an almost 
complete halt in April and May 2020, due to the national lockdowns that took place across Europe, with several countries reaching $100 \%$ negative growth in foreign visitors. Foreign visitors remained in strong negative growth across the rest of the year, after the lockdown was somewhat eased, with "high season" ranging from N. Macedonia's $-90 \%$, over BiH's and Serbia's $-85 \%$, Montenegro's $-80 \%$ to Slovenia's $-60 \%$ and Croatia's $-40 \%$. The explanation behind Slovenia's and Croatia's relative success in fighting the negative growth was their geographical position within EU and various "Covid-free" (no infection chance) solutions for foreign tourists. In case of Croatia, the director of Croatian Tourist Bureau, Kristjan Staničić, in an interview, attributed this success to the "Croatia full of Life" and "Croatia full of Magic" campaigns and announced a new campaign for 2021: "Croatia Full of New Beginnings". Domestic visitors, however, presented a completely different trend during the high season, across all 6 countries. After the almost complete halt in April-May lockdown, the growth picks up and moves to positive values for several countries. Croatia stays in negative growth, peaking at $-2 \%$ in August, followed by Montenegro's 18\% in July; N. Macedonia's peaks at 22\% in September and Serbia in August at 25\%; $\mathrm{BiH}$ reaches a solid $60 \%$ in August, while Slovenia peaks at astonishing $220 \%$ in September. The explanation behind Croatia's and Montenegro's lack of significant domestic tourist growth, also relative to other Ex-Yu countries, could be explained by their strong reliance on tourism economy, therefore the local population would seek employment in high season, instead of travelling, especially during economic crisis. Other countries recovery is explained mostly by "organic" growth, with local populations naturally following the newly emerging trends, i.e. "stayvacations". Slovenia's extraordinary growth was also supported by the Slovenian Tourist Board (STB, 2020) via the promotional campaign "The Time is now. My Slovenia", inviting Slovenians to "stayvacations" at nearest destination in Slovenia, and via government stimulus, as Slovenia rolled out seven packages in 2020.

\section{Conclusion}

The study focused on the global pandemic that halted the world during 2020 and the tremendous impact on tourism economy. Only in the first half of 2020, the international tourist numbers were down by $65 \%$, with arrivals in June plunged 93\% when compared to 2019. Even the SARS epidemic in 2003 and global economic crisis in 2008-2009 had a tiny fraction of the COVID-19 impact. The estimate is that current numbers fell back to the values before 1990. More optimistic analysis and reports, looking towards scenarios of recovery, estimate that more than 100 million jobs could return to the global travel and tourism sector during 2021, although this would still be 17\% below 2019 figures. The point of recovery should be put to 2019 levels only in the year 2023 and "catching up" to pre-pandemic projections of future growth only in 2026. Global tourism expenditure may be up to $\$ 8.1$ trillion lower than previous predictions following the implication of COVID-19.

Modified behavioural trends in tourism emerged during the pandemic, categorized as follows:

1) Health \& Safety: measures and cancellation policies are consumers' main concerns;

2) Mobility: domestic tourism has shown positive signs in many markets since people tend to travel closer. Travellers go for "staycations" or vacations close to home;

3) Last-minute bookings have increased due to volatility of pandemic-related events and the travel restrictions;

4) Nature, Rural Tourism and Road Trips have emerged as popular travel choices due to travel limitations and the quest for open-air experiences;

5) Demographics shift: travel recovery has been stronger among younger segments. "Mature" travellers and retirees will be the most impacted segments;

6) Sustainability: authenticity and "localhood", travellers have been giving more importance to creating a positive impact on local communities, increasing looking for authenticity.

These trends can be considered consequentially chained to the pandemic, i.e. the pandemic causes Health \& Safety concerns, which, along with lockdowns, shift focus on Last-Minute, Nature, etc.

Ex-Yugoslavia countries tourist overnight stays during the global pandemic are in the focus of second part of the study. Tourism economy in these countries was strongly affected by the pandemic. After analysing this information, it is clear that creating the right strategy is the main driver of recovery of tourism economy. This pandemic has left such an impact on this industry, that it will be a challenge to overcome the consequences, some of them for years to stay. Following the example of good practice can help the countries to improve their short-term and long-term strategies. As a conclusion, international organisations and national governments should focus on recovery strategies which will rebuild the industry in the shortest possible period. The crucial condition is that the pandemic is over, but it is not too early to create short and long-term plans. 


\section{References}

AlJazeera. (2020, December 29). Sarajevski turizam pao za više od 80 posto. [Sarajevo tourism fell by $80 \%$ ]. AlJazeera. Retrieved from httphttps://balkans.aljazeera.net/news/economy/2020/12/29/sarajevski-turizam-pao-za-vise-od-80-postos://b alkans.aljazeera.net/news/economy/2020/12/29/sarajevski-turizam-pao-za-vise-od-80-posto

Bosnia and Herzegovina Agency for Statistics (2021a) Retrieved from http://www.bhas.ba/Calendar/Category/19

Bosnia and Herzegovina Agency for Statistics. (2021). Retrieved from http://bhas.gov.ba/

Croatian Bureau of Statistics. Retrieved from https://www.dzs.hr

Croatian National Tourist Board. (2021). Information on Statistical Indicators - January 2020 [Informacija o statističkim pokazateljima - studeni 2020]. Retrieved January 11, 2021, from

https://www.htz.hr/hr-HR/informacije-o-trzistima/informacije-o-tijeku-sezone

Danas. (2021, February 1). TOS: u Srbiji u 2020. godini upola manje turista. [TOS: tourist numbers halved in Serbia in 2020] Danas. Retrieved https://www.danas.rs/ekonomija/tos-u-srbiji-u-2020-godini-upola-manje-turista/

Dimitrijević, U. (2020, August 1). Korona virus i turizam: Neum, morska oaza za srpske turiste. Retrieved 15 February, 2021, from https://www.bbc.com/serbian/lat/balkan-53614945

Edi Prodan. (2020, May 24). Plitvička Jezera Ruši Rekorde Od Otvaranja 45 Tisuća Posjetitelja. [Plitvice lakes breaks record since opening 45 thousand visitors].Novi List Retrieved February 12, 2021, from https://www.novilist.hr/rijeka-regija/lika-senj/od-11-do-24-svibnja-park-je-posjetilo-vise-od-45-tisuca-posje titelja/

Elborno, S. (2020, October 1). Dubai tourism: A gradual recovery. Retrieved 12 February, 2021, from http://www.emiratesnbdresearch.com/research/article/?a=dubai-tourism-sector-a-gradual-recovery-1964

Emirates News Agency. (2020, December 12). Experience UAE winter: UAE approves new strategy to boost domestic tourism. Retrieved February 15, 2021, from

https://www.zawya.com/mena/en/legal/story/Experience_UAE_winter_UAE_approves_new_strategy_to_b oost_domestic_tourism-WAM20201212102006409/

European Travel Commission. (ETC). (2020). COVID-19 RECOVERY STRATEGIES FOR NATIONAL TOURISM ORGANISATIONS. Brussels, September 2020. Retrieved from http://www.toposophy.com/files/1/2020/ETC_NTO_RECOVERY_STRATEGIES_2020_FINAL.pdf

Fotiadis, A., Polyzos, S., \& Huan, T. (2021). The good, the bad and the ugly on COVID-19 tourism recovery. Annals of tourism research, 87, 103117. https://doi.org/10.1016/j.annals.2020.103117

Government of Montenegro. Retrieved 14 February, 2020, from: www.gov.me

HrTurizam.hr. (2020, August 3). Koliko je teška situacija u Dubrovniku najbolje govori statistika. [Statistics speaks about the grave situation in Dubrovnik]. Retrieved March 10, 2021, from https://hrturizam.hr/dubrovacko-neretvanska-zupanija-u-srpnju-ostvarila-60-manje-nocenja/

Interreg Europe. (2020). Sustainable Tourism: Strategies to counteract overtourism, A Policy Brief from the Policy Learning Platform on Environment and resource efficiency. December 2020. Interreg Europe. Retrieved from https://www.interregeurope.eu/fileadmin/user_upload/plp_uploads/policy_briefs/Sustainable_Tourism_Strat egies_to_counteract_overtourism.pdf

Kampel, K. (2020). COVID-19 and tourism: Charting a sustainable, resilient recovery for small states. The Commonwealth. Retrieved from https://thecommonwealth.org/sites/default/files/inline/THT\%20163\%20FINAL.pdf

Kaushal, V., \& Srivastava, S. (2021). Hospitality and tourism industry amid COVID-19 pandemic: Perspectives on challenges and learnings from India. International journal of hospitality management, 92, 102707. https://doi.org/10.1016/j.ijhm.2020.102707

Kovačević. (2019, July 17). Broj posjetitelja na Plitvicama isti kao i prošle godine [the number of visitors to Plitivice same as last year] Poslovni. Retrieved February 18, 2021, from https://www.poslovni.hr/hrvatska/broj-posjetitelja-na-plitvicama-isti-kao-i-prosle-godine-355505

MAKSTAT Republic of North Macedonia State Statistical Office. (2021). Tourism and catering, Tourism. 
Retrieved from http://makstat.stat.gov.mk/PXWeb/pxweb/en/MakStat/MakStat_TirizamUgostitel_Turizam

Marusic, S. J. (2019, October 3). Lonely Planet Lists North Macedonia as a 'Top Destination'. Retrieved March 17, 2021, from https://balkaninsight.com/2019/10/23/lonely-planet-lists-north-macedonia-as-a-top-destination/

Ministry of Business, innovation \& employment. (2020). Tourism recovery. Retrieved from https://www.mbie.govt.nz/immigration-and-tourism/tourism/tourism-recovery/

Ministry of Tourism of Republic of Croatia. (2019). Ministarstvo turizma Republike Hrvatske. Turizam u brojkama 2019. [Ministry of Tourism of Republic of Croatia. Tourism in numbers] Retrieved from https://mint.gov.hr/UserDocsImages/AAA_2020_MINTIS/dokumenti/Turizam_u_brojkama_2019.pdf

Ministry of Tourism of Republic of Croatia. (2021). Retrieved from https://mint.gov.hr/

MONSTAT Statistical Office of Montenegro. (2021). Retrieved from https://www.monstat.org/cg/

OECD. (2020, December 14). Policy Responses to Coronavirus (COVID-19) Rebuilding tourism for the future: COVID-19 policy responses and recovery. Retrieved from http://www.oecd.org/coronavirus/policy-responses/rebuilding-tourism-for-the-future-covid-19-policy-respo nses-and-recovery-bced9859/

OECD. (2020, June 2) Tourism Policy Responses to the coronavirus (COVID-19). Retrieved from https://www.oecd.org/coronavirus/policy-responses/tourism-policy-responses-to-the-coronavirus-covid-196466aa20/

OECD. (2021, January 31). The COVID-19 crisis in Bosnia and Herzegovina. Retrieved from https://www.oecd.org/south-east-europe/COVID-19-Crisis-in-Bosnia-and-Herzegovina.pdf

PBC Statistical Office of the Republic of Serbia. (2021) Retrieved from http://data.stat.gov.rs

Pešić, A. (2019, July 18). Turistički promet na Zlatiboru nastavlja sa rastom i u 2019. Godini. [Tourist traffic in Zlatibor keeps growing in 2019]. Seebiz. Retrieved March20, 2021, from https://www.seebiz.eu/tvrtke/turisticki-promet-na-zlatiboru-nastavlja-sa-rastom-i-u-2019-godini/203652/

RCC. (2020, April 18). Bregu: Tourism in the Western Balkans already feels the pinch of COVID-19 pandemic. Retrieved March 15, 2021, from

https://www.rcc.int/news/618/bregu-tourism-in-the-westernbalkans-already-feels-the-pinch-of-covid-19-pan demic

RCC. (2020, June 8). Tourism in the Western Balkans: Where and How in the Times of the Pandemic? Retrieved March 15, 2021, from

https://www.rcc.int/news/629/tourism-in-the-western-balkans-where-and-how-in-the-times-of-the-pandemic

Republic of North Macedonia State Statistical Office. (2021). Retrieved from http://makstat.stat.gov.mk/

Republic of Slovenia Statistical Office. (2021). Retrieved from https://pxweb.stat.si

RTS. (2021). Srpski turizam danas - šta pokazuju brojke i kada ćemo ponovo slobodno da putujemo [Serbian tourism today - what numbers say and when can we travel freely again]. Retrieved from https://www.rts.rs/page/stories/sr/\%D0\%9A\%D0\%BE\%D1\%80\%D0\%BE\%D0\%BD\%D0\%B0\%D0\%B2\% D0\%B8\%D1\%80\%D1\%83\%D1\%81/story/3178/ekonomija-i-epidemija/4092398/turizam-srbija-stanje-labo vic.html

RZSS. (2020) Republic of Serbia Statistical Institute [Republički zavod za statistiku Srbije]. Retrieved from https://www.stat.gov.rs/sr-Latn/

Sarajevo.ba (2020, January 15). Sarajevo u 2019. Godini posjetili turisti iz 174 zemlje svijeta. [Sarajevo was visited by tourists from 174 countries in 2019]. Sarajevo.ba Retrieved from https://www.sarajevo.ba/bs/article/6753/sarajevo-u-2019-godini-posjetili-turisti-iz-174-drzave-svijeta

Sloboden Pecat. (2020, June 13) Bekteshi: The list of citizens who will receive 6.000 denars each for encouraging domestic tourism has been published. Sloboden Pecat 13 Jun 2020, Retrieved from https://www.slobodenpecat.mk/en/bekteshi-objavena-e-listata-na-gragani-koi-ke-dobijat-po-6-000-denari-za -pottik-na-domashniot-turizam/

Slovenia info. (2020) Tourism in numbers. Retrieved from https://www.slovenia.info/en/business/research-and-analysis/tourism-in-numbers 
Slovenian Tourist Board (2020). Retrieved from https://www.slovenia.info/en/business/the-time-is-now-my-slovenia-promotional-campaign

STA (2020, December 8). Tourism getting ready for multi-year recovery. Retrieved March 15, 2021, from https://english.sta.si/2841153/tourism-getting-ready-for-multi-year-recovery

STAT Si. (2020). Tourist arrivals and overnight stays, Slovenia. Retrieved from https://www.stat.si/statweb/en/News/Index/8992

State Statistical Office (2019). Tourism in December 2019. Retrieved from https://www.stat.gov.mk/pdf/2020/8.1.20.03_mk.pdf

Statistical Office of Montenegro. (2021) Retrieved from https://www.monstat.org

STB Singapore Tourism Board. (2020, July 22). Enterprise Singapore, Sentosa Development Corporation and Singapore Tourism Board team up with industry to encourage locals to rediscover Singapore. Retrieved from

https://www.stb.gov.sg/content/stb/en/media-centre/media-releases/Enterprise-Singapore-Sentosa-Develop ment-Corporation-and-Singapore-Tourism-Board-team-up-with-industry-to-encourage-locals-to-rediscoverSingapore.html

Tourism New Zealand. (2020, May 22). Do something New, New Zealand!. Retrieved from https://www.tourismnewzealand.com/news/do-something-new-new-zealand/

UNWTO. (2020). World Tourism Barometer and Statistical Annex. 18(6), 1-36. https://doi.org/10.18111/wtobarometereng.2020.18.1.6

World Bank. (2020). Rebuilding Tourism Competitiveness: Tourism Response, Recovery and Resilience to the COVID-19 Crisis, World Bank, Washington, DC. Retrieved from https://openknowledge.worldbank.org/handle/10986/34348

WTTC. (2018) Travel \& Tourism City Travel \& Tourism Impact 2018. WTTC: London, UK, 2018.

WTTC. (2018a). World Travel \& Tourism Council: Montenegro 3rd Destination By Growth In 2018. Retrieved from https://senat.me/en/world-travel-tourism-council-montenegro-3rd-destination-by-growth-in-2018/

Xinhua. (2020, May 13). Number of tourists in North Macedonia drops 18.3 pct in Q1. Xinhua. Retrieved 21 Fberuary, 2021, from http://www.china.org.cn/world/Off_the_Wire/2020-05/13/content_76037478.htm

Xu, M., \& Agačević, A. (2020). Chinese Tourists as a Sustainable Boost to Low Seasons in Ex-Yugoslavia Destinations. Sustainability 2020, 12(2), 449. https://doi.org/10.3390/su12020449

\section{Copyrights}

Copyright for this article is retained by the author(s), with first publication rights granted to the journal.

This is an open-access article distributed under the terms and conditions of the Creative Commons Attribution license (http://creativecommons.org/licenses/by/4.0/). 